\title{
Seed Geranium Growth and Flowering Responses to Uniconazole
}

\section{Terri Woods Starman ${ }^{1}$, Teresa A. Cerny ${ }^{2}$, and Tracy L. Grindstaff ${ }^{3}$ Department of Ornamental Horticulture and Landscape Design, University of Tennessee, Knoxville, TN 37901-1071}

Additional index words. growth retardant, Pelargonium $\times$ hortorum, XE-1019

\begin{abstract}
Height control and flowering responses to uniconazole spray or drench treatments were measured for 'Multibloom Scarlet' and 'Red Elite' geranium (Pelargonium $\times$ hortorum L.H. Bailey). Total plant height of both cultivars was reduced proportionately to the height of a $10-\mathrm{cm}$ container when the uniconazole drench concentration was 0.025 $\mathrm{mg}$ a.i./pot. Used as a spray, uniconazole was not as effective in restricting total plant height of either cultivar. Foliage height was shortened more than inflorescence height. Inflorescence diameter was decreased with increasing uniconazole drench concentrations. Sprays did not affect inflorescence diameter of either cultivar. Uniconazole effect on days to flower varied with cultivar and application method. Chemical name used: $(E)-(S)-1-(4-$ chlorophenyl)-4,4-dimethyl-2-(1,2,4-triazol-1-yl)-pent-1-ene-3-ol (uniconazole).
\end{abstract}

Triazole growth retardants cause alterations of growth and flowering processes in geranium, and the incidence of these changes varies among cultivars. Paclobutrazol reduced days to flower of 'Mustang' geranium (Cox, 1991), and uniconazole did the same with 'Ringo Deep Scarlet' (Keever and Foster, 1991). However, triazole growth retardants did not affect time to flower of 'Smash Hit' or 'Yours Truly' geranium (Cox and Keever, 1988; Tayama and Carver, 1990). Uniconazole restricted the height of geraniums produced from cuttings (Tayama and Carver, 1990) and seed (Keever and Foster, 1991), and paclobutrazol controlled height of seed geraniums (Cox, 1991; Cox and Keever, 1988). The objective of our experiment was to determine the utility of uniconazole spray or drench to control height and flowering response of two new geranium cultivars, 'Multibloom Scarlet' and 'Red Elite'.

\section{Materials and Methods}

Seeds of 'Multibloom Scarlet' and 'Red Elite' (Goldsmith Seeds, Gilroy, Calif.) were sown 25 Sept. 1992 in bedding plant flats containing Jiffy Mix (Jiffy Products of America, West Chicago, Ill.) and placed under mist until emergence. Seedlings were transplanted to 0.4-liter $(10-\mathrm{cm})$ plastic pots containing ProMix BX (Premier Brands, New Rochelle, N.Y.) after the first true leaves had developed. Plants were grown in a $24 / 18 \mathrm{C}$

Received for publication 8 Nov. 1993. Accepted for publication 4 Apr. 1994. Use of trade names does not imply endorsement of the products named nor criticism of similar ones not named. The cost of publishing this paper was defrayed in part by the payment of page charges. Under postal regulations, this paper therefore must be hereby marked advertisement solely to indicate this fact.

${ }^{1}$ Assistant Professor.

${ }^{2}$ Graduate Research Assistant.

${ }^{3}$ Undergraduate Research Assistant. (venting/night temperature set points) glasshouse in full sun. Fertilizer was applied in the irrigation water at $20 \mathrm{~N}-4.4 \mathrm{P}-16.6 \mathrm{~K}$ with $\mathrm{N}$ at $100 \mathrm{mg} \cdot$ liter $^{-1}$ until final transplanting and at $200 \mathrm{mg} \cdot \mathrm{liter}^{-1}$ thereafter. Plants were leached every fourth watering.

Growth retardants were applied 6 weeks $\mathrm{C}=$ cubic after sowing when plants had at least five leaves with a diameter $\geq 2.5 \mathrm{~cm}$ (Jeannine Bogard, Goldsmith Seeds, personal communication). Uniconazole was sprayed on foliage at $\approx 200 \mathrm{ml}$ of solution applied evenly over $1 \mathrm{~m}^{2}$ of bench space. Uniconazole at 5.0, 10.0, and $20.0 \mathrm{mg} \cdot \mathrm{liter}^{-1}$ was sprayed only once. Spray rates were chosen based on earlier trials where uniconazole spray at 10.0 or $20.0 \mathrm{mg} \cdot \mathrm{liter}^{-1}$ controlled height of 'Sprinter Scarlet', 'Sunbelt Scarlet', and 'Sunbelt Hot Pink' geranium grown in 0.4-liter pots similarly to 2-chloro$N, N, N$-trimethylethanaminium chloride (chlormequat chloride) at $1500 \mathrm{mg} \cdot \mathrm{liter}^{-1}$ (unpublished data).

Other uniconazole treatments were applied in a $125-\mathrm{ml} /$ pot growth medium drench at $0.025,0.05$, or $0.10 \mathrm{mg}$ a.i./pot. For comparison, chlormequat chloride treatments had been $750 \mathrm{mg} \cdot \mathrm{liter}^{-1}$ foliar spray to runoff and 750 $\mathrm{mg}$ a.i./pot drench applied in $125 \mathrm{ml} /$ pot. Controls included water applied as a foliar spray and as a drench $(125 \mathrm{ml} / \mathrm{pot})$. All drench treatments were applied coincident with foliar spray treatments, but on separate plants. Data were collected 14 weeks after sowing when plants were judged to be marketable.

Data taken at harvest included total plant height, measured from pot rim to the top of the tallest inflorescence, and foliage height, measured from pot rim to the uppermost leaf held
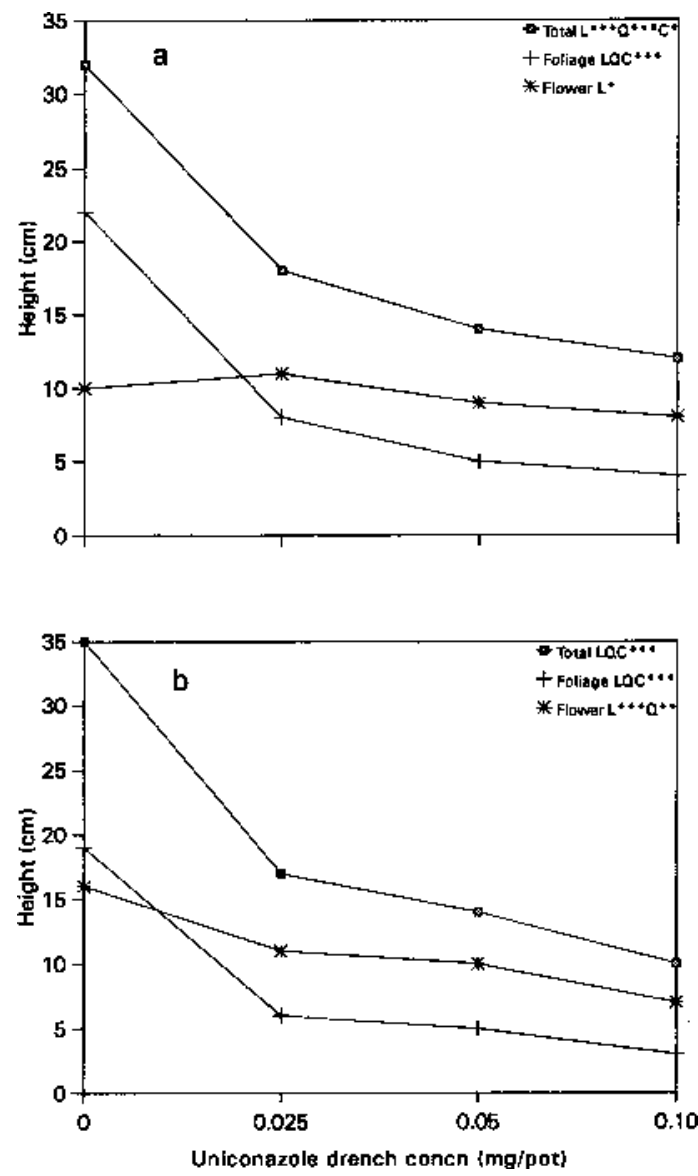

Fig. 1. Effects of uniconazole drench concentration (in $\mathrm{mg}$ a.i./pot) on total plant height ( $\square$ ), foliage height $(+)$, and flower (inflorescence) height (*) of (a) 'Red Elite' and (b) 'Multibloom Scarlet' geranium. vs, *******NNonsignificant or significant at $P \leq 0.05,0.01$, or 0.001 , respectively. $\mathrm{L}=$ linear, $\mathrm{Q}=$ quadratic, and 
parallel to the growth medium surface. Inflorescence height was the remainder after subtracting foliage height from total plant height. Based on the standard 1.5 to 2 times the container height guideline used to produce a quality plant (Sachs et al., 1976), plant height should be 15 to $20 \mathrm{~cm}$ in a $10-\mathrm{cm}$ pot. Inflorescence diameter was measured across the largest fully open inflorescence. Days to flower (DTF) were determined as the number of days from seed sowing until the first flower within an inflorescence opened, exposing pistil and stamens.

The experiment consisted of 10 treatments using 10 single-plant replications in a completely randomized design. Data were subjected to one-way analysis of variance, and single degree of freedom contrasts were conducted for appropriate comparisons. Analogous controls were included in the trend analysis as zeros. Orthogonal polynomial coefficients were those appropriate for unequally spaced treatments. Chlormequat chloride, another growth retardant used on geraniums (Miranda and Carlson, 1980), was compared to each uniconazole treatment using $t$ tests.

\section{Results}

Total plant height of both cultivars was reduced proportionate to the height of the container $(15-20 \mathrm{~cm})$ when the uniconazole drench concentration was $0.025 \mathrm{mg}$ a.i./pot (Fig. 1). When used as a drench, the relation between increasing concentration and reduction in total plant height was cubic; foliage height was affected similarly. Inflorescence height reduction was more gradual.

Used as a spray, uniconazole was not as effective as a drench in reducing total plant height of either cultivar (Fig. 2). Plants remained taller than $20 \mathrm{~cm}$ with all concentrations. Foliage height was reduced less with the spray treatment than with the drench and there was little effect on flower height.

Inflorescence diameter was affected differently by the two application methods (Table 1 ); it was reduced with increasing uniconazole drench concentrations (cubic for 'Red Elite', linear for 'Multibloom Scarlet'), but neither cultivar was affected by uniconazole sprays.

Uniconazole drench had an inconsistent effect on DTF for 'Red Elite' and no effect on 'Multibloom Scarlet'. With spray treatment, DTF increased linearly with increasing uniconazole concentration on 'Red Elite'. The relationship was opposite for 'Multibloom Scarlet'-DTF decreased as spray concentration increased.

Chlormequat chloride sprays or drenches restricted total plant height of both cultivars to between 15 and $20 \mathrm{~cm}$ (data not shown). Both cultivars had similar $(42 \%)$ reduction in inflorescence height with chlormequat chloride drench, but only 'Multibloom Scarlet' had a reduction $(24 \%)$ when sprayed. Inflorescence diameter was always reduced more with chlormequat chloride than uniconazole. With chlormequat chloride, the average reduction for the two cultivars compared to the controls was $19 \%$ for spray and $30 \%$ for drench appli-
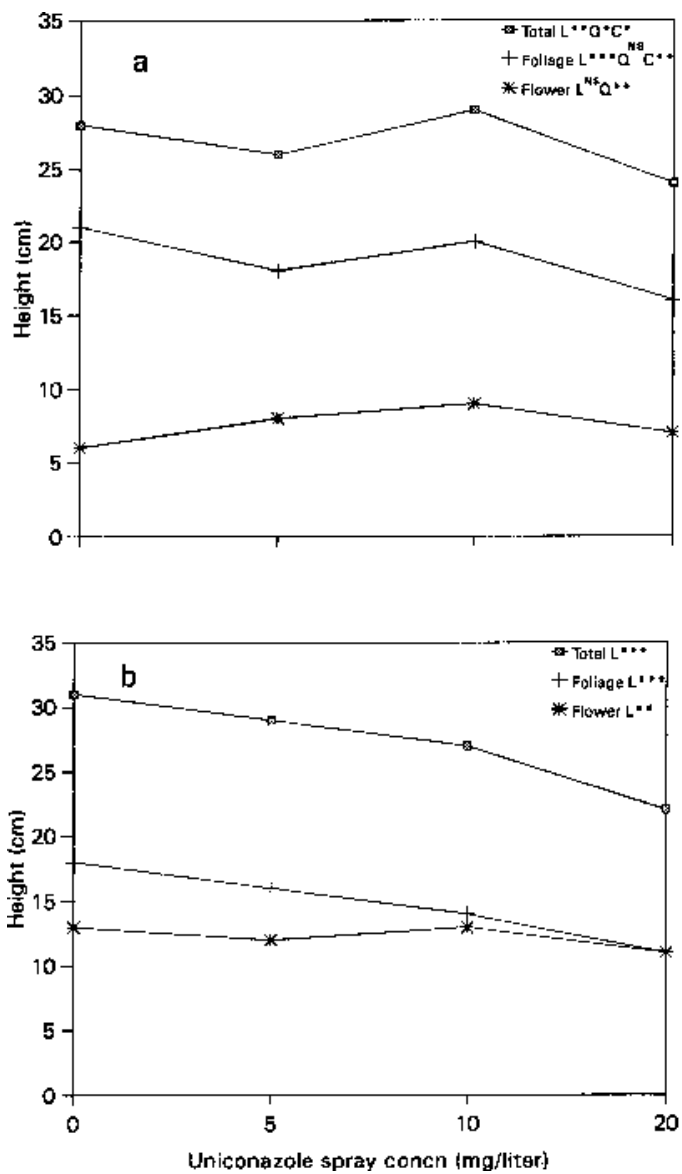

Fig. 2. Effects of uniconazole spray concentration (in mg.liter ${ }^{-1}$ ) on total plant height ( $\square$ ), foliage height (+), and flower (inflorescence) height (*) of (a) 'Red Elite' and (b) 'Multibloom Scarlet' geranium.

ns, *,**,*** Nonsignificant or significant at $P \leq 0.05,0.01$, or 0.001 , respectively. $\mathrm{L}=$ linear, $\mathrm{Q}=$ quadratic, and $\mathrm{C}=$ cubic.

cation. Compared to controls, DTF was shortened by 4 days when 'Red Elite' was drenched and by 3 days when 'Multibloom Scarlet' was sprayed. DTF were increased by 4 days when 'Multibloom Scarlet' was drenched.

\section{Discussion}

The highest spray concentration used in this study (20 mg.liter ${ }^{-1}$ ) was not adequate to maintain plant height below twice the container height. If greater height control is desired, higher spray concentrations would need to be tested. Other studies testing uniconazole on seed and cutting geranium showed this rate to be sufficient. Uniconazole spray applied twice (once beginning when laterals had $4 \mathrm{~cm}$ of new growth after pinching and again 2 weeks later) at $10 \mathrm{mg} \cdot \mathrm{liter}^{-1}$ gave height control similar to chlormequat chloride at 1500 mg.liter ${ }^{-1}$ for 'Yours Truly' cutting geranium grown in 0.5-liter containers (Tayama and Carver, 1990). Uniconazole sprays at 15 or 20 $\mathrm{mg} \cdot \mathrm{liter}^{-1}$ applied 2 weeks after transplanting into 0.4-liter pots, when plants were $9.5 \mathrm{~cm}$ tall, reduced height and width of 'Ringo Deep Scarlet'; rates of 1, 3, 5, or $10 \mathrm{mg} \cdot$ liter $^{-1}$ did not (Keever and Foster, 1991).

Table 1. Effect of uniconazole on flowering of 'RedElite'(RE) and'Multibloom Scarlet' (MS) geranium.

\begin{tabular}{|c|c|c|c|c|}
\hline \multirow{2}{*}{$\begin{array}{l}\text { Uniconazole } \\
\text { concn }\end{array}$} & \multicolumn{2}{|c|}{ Inflorescence diam $(\mathrm{cm})$} & \multicolumn{2}{|c|}{ Days to flower } \\
\hline & RE & $\mathrm{MS}$ & $\mathrm{RE}$ & MS \\
\hline \multicolumn{5}{|c|}{ Drench (mg a.i./pot) } \\
\hline 0 & 9.4 & 10.4 & 94 & 86 \\
\hline 0.025 & 8.3 & 9.7 & 90 & 86 \\
\hline 0.05 & 8.8 & 9.2 & 94 & 85 \\
\hline 0.10 & 8.6 & 8.5 & 90 & 86 \\
\hline Significance & $\mathrm{L}^{\mathrm{Ns}}, \mathrm{Q}^{\mathrm{Ns}}, \mathrm{C}^{*}$ & $\mathrm{~L}^{* * *}$ & $L^{\mathrm{Ns}}, Q^{\mathrm{Ns}}, C^{* *}$ & NS \\
\hline \multicolumn{5}{|c|}{ Spray $\left(\mathrm{mg} \cdot\right.$ liter $\left.^{-1}\right)$} \\
\hline 0 & 8.6 & 9.6 & 90 & 89 \\
\hline 5 & 8.7 & 10.1 & 93 & 85 \\
\hline 10 & 8.7 & 9.7 & 93 & 86 \\
\hline 20 & 8.7 & 10.1 & 94 & 85 \\
\hline Significance & NS & NS & $\mathrm{L}^{*}$ & $\mathrm{~L}^{*}$ \\
\hline
\end{tabular}


According to the label, uniconazole should be sprayed on foliage of seed geranium at 2 to $4 \mathrm{mg} \cdot$ liter $^{-1}$ when plant height is $\approx 10 \mathrm{~cm}$ (Valent USA Corp., 1993). Evidence suggests the optimum uniconazole concentration for controlling geranium height depends on cultural methods such as time of application or size of container. In earlier trials, uniconazole spray at 3.0 or $5.0 \mathrm{mg} \cdot$ liter $^{-1}$ controlled height of seed geranium grown in plug flats (288 cells/flat) when the growth retardant was applied at the first or second true leaf stage as seedlings first began to elongate. Concentrations of 10.0 or $20.0 \mathrm{mg}$ liter $^{-1}$ were needed when plants were sprayed 4 weeks after transplanting into 0.4 liter pots (unpublished data). Uniconazole treatment timed to earlier stages of plant development were more effective in controlling chrysanthemum [Dendrathema $\times$ grandiflorum (Ramat.) Kitamura] (Gilbertz, 1992) and ornamental pepper (Capsicum annuиm L.) (Starman, 1993) height.

A uniconazole drench gave similar height control of 'Red Elite' and 'Multibloom Scarlet' when applied at $0.025 \mathrm{mg}$ a.i./pot. Differences between spray and drench effectiveness concur with previous research using triazole growth retardants on floricultural crops. Paclobutrazol drenches resulted in significantly greater growth suppression than sprays on
'Smash Hit' geranium (Cox and Keever, 1988). Tayama and Carver (1992) found uniconazole at 0.6 to $1.2 \mathrm{mg}$ a.i./pot to be excessive on cutting geranium. We believe that ours is the first study to determine a uniconazole drench rate for seed geranium that was not excessive.

Inflorescence diameter was reduced less with uniconazole than with the conventional chlormequat chloride treatment, an effect that would be desirable commercially. DTF results were inconsistent in this study. In cases where DTF was lessened, the difference was only by 4 days - probably not economically advantageous. Effects of triazole growth retardants on flowering varied in relation to height control. While height control was concentration dependent, flowering was not. Using triazole growth retardants on geranium has resulted in early flowering when height control was optimum (Keever and Foster, 1991) or excessive (Cox, 1991), no effect on flowering when height control was optimum (Tayama and Carver, 1992) or excessive (Cox and Keever, 1988), and delayed flowering when height control was excessive (Tayama and Carver, 1990). Further research is needed to determine if applying triazole growth retardant before flower initiation is requisite to earlier flowering in geranium, as it is with chlormequat chloride.

\section{Literature Cited}

Cox, D.A. 1991. Gibberellic acid reverses effects of excess paclobutrazol on geranium. HortScience 26:39-40.

Cox, D.A. and G.J. Keever. 1988. Paclobutrazol inhibits growth of zinnia and geranium. HortScience 23:1029-1030.

Gilbertz, D.A. 1992. Chrysanthemum response to timing of paclobutrazol and uniconazole sprays. HortScience 27:322-323.

Keever, G.J. and W.J. Foster. 1991. Production and postproduction performance of uniconazole-treated bedding plants. J. Environ. Hort. 9(4):203-206.

Miranda, R.M. and W.H. Carlson. 1980. Effect of timing and number of applications of chlormequat and ancymidol on the growth and flowering of seed geraniums. J. Amer. Soc. Hort. Sci. 105:273-277.

Tayama, H.K. and S.A. Carver. 1990. Zonal geranium growth and flowering responses to six growth regulators. HortScience 25:82-83.

Tayama, H.K. and S.A. Carver. 1992. Concentration response of zonal geranium and potted chrysanthemum to uniconazole. HortScience 27:126-128.

Sachs, R.M., A.M. Kofranek, and W.P. Hackett. 1976. Evaluating new pot plant species. Florists Rev. 159(4116):35-36, 80-84.

Starman, T.W. 1993. Ornamental pepper growth and fruiting response to uniconazole depends on application time. HortScience 28:917-919.

Valent USA Corp. 1993. Sumagic plant growth regulator, Manufacturer form 219-E. Valent USA Corp., Walnut Creek, Calif. 